\title{
Primary small cell carcinoma of the liver, a rare entity
}

\author{
Martine Otten, ${ }^{1}$ Shahrzad Sepehrkhouy, ${ }^{2}$ Kaspar van Everdingen, ${ }^{3}$ Lenneke Haas ${ }^{1}$
}

${ }^{1}$ Department of Intensive Care, Diakonessenhuis Utrecht, Utrecht, The Netherlands ${ }^{2}$ Department of Pathology, Diakonessenhuis Utrecht, Utrecht, The Netherlands ${ }^{3}$ Department of Radiology, Diakonessenhuis Utrecht, Utrecht, The Netherlands

\section{Correspondence to} Lenneke Haas, lennekehaas@hotmail.com
CrossMark

\footnotetext{
To cite: Otten $\mathrm{M}$,

Sepehrkhouy S, van

Everdingen $\mathrm{K}$, et al. BMJ

Case Rep Published online:

[please include Day Month

Year] doi:10.1136/bcr-2013-

201990
}

\section{DESCRIPTION}

A 77-year-old man presented to the emergency room with a 3-week history of progressive abdominal discomfort. His medical history revealed hypertension and chronic obstructive pulmonary disease (COPD). His symptoms consisted of nausea, anorexia, weight loss, constipation and dyspnoea d'effort.

Clinical examination revealed jaundice and a diffusely painful abdomen. Laboratory results included elevated $\mathrm{C}$ reactive protein $(51(<10) \mathrm{mg} / \mathrm{L})$ and erythrocyte sedimentation rate $(13(1-7) \mathrm{mm} / \mathrm{h})$, renal insufficiency (urea $18(2.9-7.5) \mathrm{mmol} / \mathrm{L}$ and creatinine $180(62-106) \mu \mathrm{mol} / \mathrm{L})$ and elevated liver enzymes (bilirubin $135(<17) \mu \mathrm{mol} / \mathrm{L}$, with conjugated bilirubin $117(<5) \mu \mathrm{mol} / \mathrm{L}$, alkaline phosphatase $353(<115) \mathrm{U} / \mathrm{L}, \mathrm{GGT} 1050(<55) \mathrm{U} / \mathrm{L}$, alanine transaminase $154(<45) \mathrm{U} / \mathrm{L}$, aspartate aminotransferase $190(<35) \mathrm{U} / \mathrm{L}$, lactate dehydrogenase 425 $(<220) \mathrm{U} / \mathrm{L})$. An abdominal ultrasound showed an inhomogeneously enlarged liver which was suspected to be metastatic disease. Subsequently, a diagnostic ascitic fluid sample was taken and a CT was performed (figure 1).

The next day, the patient developed a severe lactic acidosis (lactic acid $13 \mathrm{mmol} / \mathrm{L}, \mathrm{pH} 7.14$, $\mathrm{pCO}_{2} \quad 1.9 \mathrm{kPa}, \quad \mathrm{HCO}_{3} \quad 4.8 \mathrm{mmol} / \mathrm{L}, \quad \mathrm{BE}$ $-21.1 \mathrm{mmol} / \mathrm{L}$ ), with impending respiratory exhaustion, and he was admitted to the intensive care unit. He was resuscitated and a liver biopsy was performed which revealed a small cell carcinoma. Cytology of the ascites also showed signs of metastases of small cell carcinoma.

Considering the very poor prognosis, treatment was restricted to pain control and comfort care, after which the patient soon passed away. Autopsy revealed an enlarged liver that was almost fully superseded by primary small cell carcinoma (figure 2), metastatic disease in the bone marrow and lymph nodes and extensive ischaemia of the small intestine and colon.

\section{Learning points}

- Small cell carcinoma (SCC) usually arises in the lung, but can also originate in a wide range of extrapulmonary sites, including the liver, oesophagus, stomach, colon, gallbladder, cervix and skin. However, extrapulmonary SCCs are extremely rare. ${ }^{1-3}$

- Malignant disease can present with intestinal ischaemia.

- Lactic acidosis is suggestive, although not specific, for intestinal ischaemia.

- Abdominal ultrasound can be more sensitive than $\mathrm{CT}$ in cases like these with widespread metastatic liver disease when the liver was entirely superseded, leaving almost no normal liver parenchyma. 

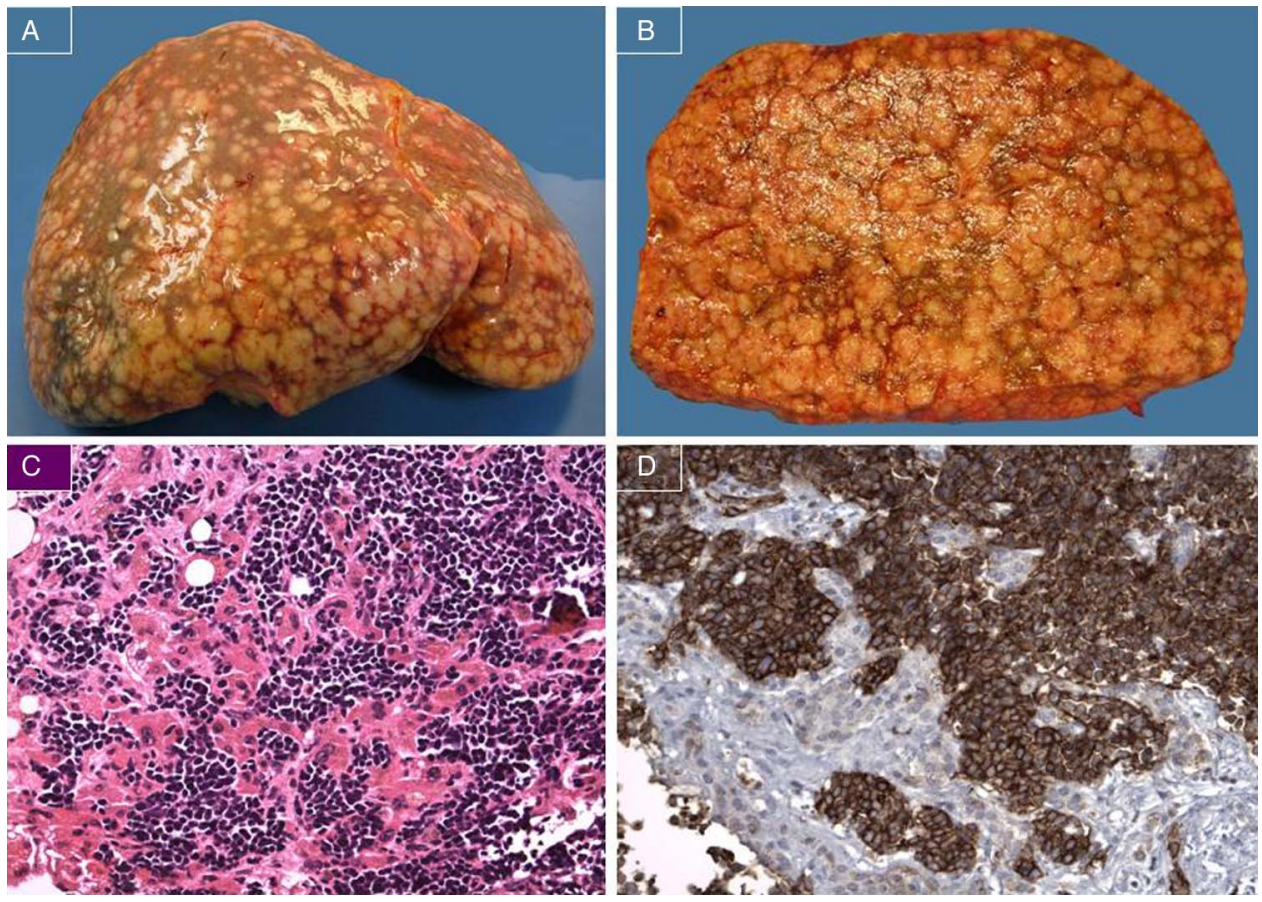

Figure 2 Histology: macroscopy and microscopy. (A) and (B) Grossly enlarged liver (5406 g) with multiple, irregular small nodules. (C) H\&E staining; liver with infiltration of malignant cells with a solid growth pattern. The tumour cells have hyperchromatic nuclei, 'salt and pepper'-chromatin and inspicious nucleoli (original magnification $\times 20$ ). (D) Immunohistochemical staining for CD56 showing a strongly positive reaction consistent with a small cell carcinoma (original magnification $\times 20$ ).

Contributors $\mathrm{MO}$, SS, KvE and LH contributed significantly towards the writing of the manuscript and approved the final manuscript for publication.

Competing interests None.

Patient consent Obtained.

Provenance and peer review Not commissioned; externally peer reviewed.

\section{REFERENCES}

1 Frazier SR, Kaplan PA, Loy TS. The pathology of extrapulmonary small cell carcinoma. Semin Oncol 2007;34:30-8.

2 Kaman L, Iqbal J, Pall M, et al. Primary small cell carcinoma of liver: A rare tumor. Gastroenterology Res 2010;3:180-4.

3 Kim YH, Kwon R, Jung GJ, et al. Extrapulmonary small-cell carcinoma of the liver. J Hepatobiliary Pancreat Surg 2004;11:333-7.

Copyright 2013 BMJ Publishing Group. All rights reserved. For permission to reuse any of this content visit

http://group.bmj.com/group/rights-licensing/permissions.

BMJ Case Report Fellows may re-use this article for personal use and teaching without any further permission.

Become a Fellow of BMJ Case Reports today and you can:

- Submit as many cases as you like

- Enjoy fast sympathetic peer review and rapid publication of accepted articles

- Access all the published articles

- Re-use any of the published material for personal use and teaching without further permission

For information on Institutional Fellowships contact consortiasales@bmjgroup.com

Visit casereports.bmj.com for more articles like this and to become a Fellow 